Article

\title{
Eco-Friendly UPLC-MS/MS Method for Determination of a Fostamatinib Metabolite, Tamatinib, in Plasma: Pharmacokinetic Application in Rats
}

\author{
Essam Ezzeldin ${ }^{1,2,3, *}$, Muzaffar Iqbal ${ }^{1,2}{ }^{\oplus}$, Yousif A. Asiri ${ }^{4}$, Ahmed Y. A. Sayed ${ }^{1}$ and Rashad Alsalahi ${ }^{1}$ \\ 1 Department of Pharmaceutical Chemistry, College of Pharmacy, King Saud University, \\ Riyadh P.O. Box 11451, Saudi Arabia; muziqbal@ksu.edu.sa (M.I.); ahmedyahia@gmail.com (A.Y.A.S.); \\ ralsalahi@KSU.EDU.SA (R.A.) \\ 2 Bioavailability Unit, Central Laboratory, College of Pharmacy, King Saud University, \\ Riyadh P.O. Box 11451, Saudi Arabia \\ 3 Drug Bioavailability Center, National Organization for Drug Control and Research, Cairo P.O. Box 29, Egypt \\ 4 Department of Clinical Pharmacy, College of Pharmacy, King Saud University, \\ Riyadh P.O. Box 11451, Saudi Arabia; yasiri@ksu.edu.sa \\ * Correspondence: esali@ksu.edu.sa; Tel.: +966-596351220
}

check for updates

Citation: Ezzeldin, E.; Iqbal, M.; Asiri, Y.A.; Sayed, A.Y.A.; Alsalahi, R. Eco-Friendly UPLC-MS/MS Method for Determination of a Fostamatinib Metabolite, Tamatinib, in Plasma: Pharmacokinetic Application in Rats. Molecules 2021, 26, 4663. https:// doi.org/10.3390/molecules 26154663

Academic Editors: Manuel Sergi and Camilla Montesano

Received: 15 April 2021

Accepted: 13 July 2021

Published: 31 July 2021

Publisher's Note: MDPI stays neutral with regard to jurisdictional claims in published maps and institutional affiliations.

Copyright: (c) 2021 by the authors. Licensee MDPI, Basel, Switzerland. This article is an open access article distributed under the terms and conditions of the Creative Commons Attribution (CC BY) license (https:// creativecommons.org/licenses/by/ $4.0 /)$.
Abstract: Fostamatinib is a prodrug of the active metabolite tamatinib, which is a spleen tyrosine kinase (Syk) inhibitor used in the treatment of primary chronic adult immune thrombocytopenia and rheumatoid arthritis. A highly sensitive, rapid, reliable, and green method was developed and validated using ultra-performance liquid chromatography and tandem mass spectrometry (UPLC-MS/MS) for quantification of tamatinib in rat plasma. Ibrutinib was used as internal standard and liquid-liquid extraction was applied using tert-butyl methyl ether. The analyte was separated on an Acquity ${ }^{\mathrm{TM}} \mathrm{CSH} \mathrm{C}_{18}(2.1 \mathrm{~mm} \times 100 \mathrm{~mm}, 1.7 \mu \mathrm{m})$ column using mobile phase consisting of $10 \mathrm{mM}$ ammonium acetate and acetonitrile (10:90) and the flow rate was $0.25 \mathrm{~mL} / \mathrm{min}$. Electrospray ionization (ESI) was carried out in positive mode. Quantitation of tamatinib and the IS was performed using multiple reaction monitoring mode with precursor-to-product transitions of $\mathrm{m} / \mathrm{z} 471.1>122.0$ and $m / z 441.1>84.0$, respectively. The calibration range was $0.1-1000.0 \mathrm{ng} / \mathrm{mL}$ and the linearity of the method was $\geq 0.997$. The developed method greenness was investigated. All principal parameters for the method, including linearity, accuracy, precision, recovery, and stability, were within acceptable ranges. Tamatinib pharmacokinetic study in rats was successfully carried out using the developed method.

Keywords: fostamatinib; tamatinib; UPLC-MS/MS; pharmacokinetics; rat

\section{Introduction}

Fostamatinib is an oral Syk inhibitor that is effective in the treatment of malignant clones through inhibition of antigen-dependent BCR signals [1,2]. Fostamatinib is a prodrug of the active compound, tamatinib, which is a relatively selective Syk inhibitor used to treat rheumatoid arthritis [3,4], especially in patients with poor therapeutic response to methotrexate [5]. It is also used to treat thrombocytopenia, a shortage of blood platelets needed for normal blood clotting [6]. A recent study reported that mice treated with fostamatinib showed less fibrosis and inflammation in lung tissue [7]. Moreover, fostamatinib has a therapeutic option for limiting breast cancer metastasis [8] and for treatment of rheumatoid arthritis [9]. The drug can induce time- and dose-dependent decline in cell viability that is linked to apoptosis activation. This activity causes a reduction in tumor growth and was enhanced in combinations with other treatments, including bortezomib, rituximab, and dexamethasone [10]. However, dropout and subsequent loss of efficacy during fostamatinib treatment increased with the increases of its dose [3]. 
Fostamatinib administration shows variable effects on the pharmacokinetics of other drugs. Clinical investigations indicate that co-administration of fostamatinib increased the rate and extent of absorption of ethinyl estradiol, simvastatin, or rosuvastatin, but had no impact on the pharmacokinetics of warfarin [11] or methotrexate in rheumatoid arthritis patients [12]. Therapeutic effects of fostamatinib in chronic lymphocytic leukemia (CLL) was successfully tested in mice [13] and in clinical trials (phase I and II studies) with proven efficacy and safety in patients with CLL and B cell non-Hodgkin lymphoma (NHL) [2].

Administration of fostamatinib during pregnancy caused urogenital and cardiovascular abnormalities through kidney and ureteral agenesis and a specific major vessel abnormality of the retroesophageal right subclavian artery [14]. Tamatinib displays minimal functional immunotoxicity [15]. In experimental nephrotoxic nephritis in rats, tamatinib reduced glomerular macrophage infiltration, tissue injury, and proteinuria [16]. It also reduced renal monocyte chemoattractant protein glomerulonephritis in a time-dependent manner and improved renal function [16].

Fostamatinib hydrolyzes rapidly to tamatinib by intestinal alkaline phosphatases. It is highly bioavailable with dose-dependent systemic exposure [17]. A study carried out both in vitro and in humans showed that fostamatinib was rapidly transformed to tamatinib by human intestinal microsomes [18,19]. After oral administration of fostamatinib, tamatinib was the major metabolite in plasma while fostamatinib plasma levels were very low [20]. An in-vitro study confirmed that tamatinib is metabolized by CYP3A4 via O-demethylation. Rifampicin (a CYP3A4 inducer) decreased tamatinib blood levels [11]. Concurrent administration of ketoconazole and verapamil with fostamatinib increases tamatinib levels, attributable inhibition of CYP3A4. Fostamatinib lowered concentrations of pioglitazone and its metabolite hydroxy pioglitazone, increased pioglitazone AUC, and decreased production of the hydroxy metabolite. These observations demonstrated that tamatinib is a CYP2C8 inducer [11]. Dose escalation of fostamatinib showed a linear response with rapid onset. In vitro, tamatinib downregulated macrophages stimulated with aggregated IgG and MCP-1 produced from mesangial cells [16].

Tamatinib induces progressive improvement in histopathology, clinical scores, and joint radiography in collagen-induced arthritis in rodents [21]. Tamatinib is used in therapy for glomerulonephritis through targeting of Syk [16] and has shown efficacy and safety in patients with NHL [22]. Tamatinib, as a Syk inhibitor, acts with TGF- $\beta$ to decrease cell viability. These actions result in a reduction in progression through the cell cycle and increased cell apoptosis [23]. Tamatinib infusion increases blood pressure in anesthetized rats. It inhibits vascular endothelial growth factors dose-dependently [24]. It also increases femoral arterial conductance [5].

Tamatinib, like most TYK inhibitor drugs, has a narrow therapeutic margin. Therefore, individualization of the dose is necessary for safe and efficacious use. Consequently, a sensitive, precise, and accurate method is needed for dose adjustment. There is a lack of fully validated methods for tamatinib determination in plasma. The purpose of this work was to develop an accurate, rapid, and eco-friendly method for detection of tamatinib in rat plasma using UPLC-MS/MS and to apply this method in a pharmacokinetic study.

\section{Results and Discussion}

\subsection{Optimization of Chromatographic Condition}

In chromatographic analysis, the efficiency of analytical methods to separate the analyte and IS depends on its sensitivity, which is represented by LLOD or LLOQ. Both mass spectrometry and chromatographic conditions were optimized. Tamatinib and IS (500 ng/mL) were injected into the mass spectrometer with a flow rate of $5 \mu \mathrm{L} / \mathrm{min}$. Higher sensitivity for both analyte and IS was obtained using the positive ionization mode. The most abundant fragment ions were found at $m / z 122.0$ and 84.0 for the analyte and IS, respectively, and MRM fragmentation of $[\mathrm{M}+\mathrm{H}]^{+} 471.1>122.0$ and $441.1>84.0$ were applied for quantitation of the analyte and IS, respectively (Figure 1). 


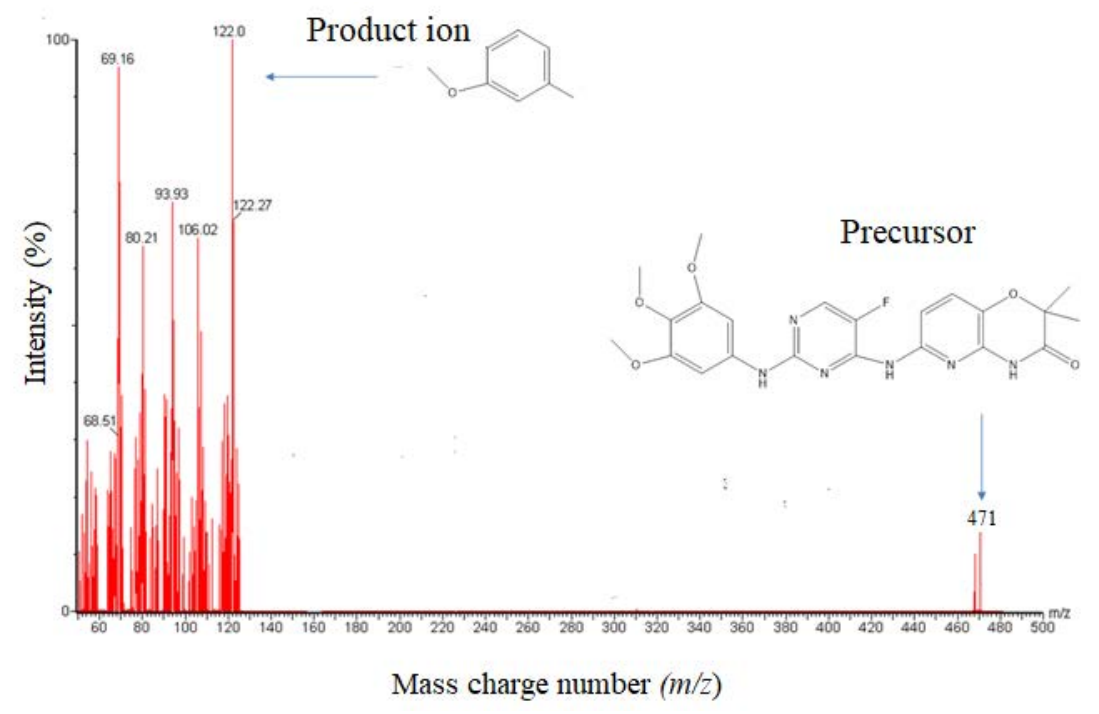

Figure 1. Typical Representation of Precursor-to-Product Ion Spectra of Tamatinib using ESI Positive Ionization Mode.

To achieve the best separation, HILIC, Acquity BEH $\mathrm{C}_{18}$ and Acquity $\mathrm{CSH} \mathrm{C}_{18}$ columns were tested. The best column for sensitivity and resolution was Acquity ${ }^{\mathrm{TM}}$ (Milford, MA 01757, USA) UPLC CSH C18 $(2.1 \mathrm{~mm} \times 100 \mathrm{~mm}, 1.7 \mu \mathrm{m})$. Acetonitrile and methanol were tested as solvents with various amounts of ammonium acetate or ammonium format. The most efficient mobile phase with the best retention times for the analyte and IS was acetonitrile with $10 \mathrm{mM}$ ammonium acetate (90:10) at an elution rate of $0.25 \mathrm{~mL} / \mathrm{min}$.

\subsection{Sample Preparation}

Sample preparation is the most important process in a bioanalytical method because it can remove endogenous and other substances to yield higher sensitivity. Protein precipitation, the simplest method in drug analysis, was assessed. However, the recovery or method efficiency was low. This result may reflect suppression arising from interfering endogenous bio-components among the solvents-ethyl acetate, diethyl ether, MTBE, and dichloromethane - tested for extraction of tamatinib and IS. MTBE showed the highest recovery. Finally, a combination of cleanup methods-namely, protein precipitation before liquid-liquid extraction with MTBE-was used to obtain the highest recovery and sensitivity for the analysis of the analyte and IS.

\subsection{Method Validation}

FDA guidelines for bioanalytical methods were followed to validate the present method. The validation comprises of accuracy, precision, extraction recovery, matrix effects, and stability studies. Three concentration levels of QC samples, across the range of CC, were evaluated (LOQ, MQC, and HQC) along with LLOQ.

\subsubsection{Selectivity and Sensitivity}

No interfering peaks were found at the retention time of tamatinib and IS following analysis of blank plasma extracted using the same extraction and separation method using the optimized UPLC-MS/MS condition. Figure 2 shows a typical chromatogram of the extracted blank rat plasma. Sensitivity, or the relationship between the analyte signal and the concentration, is very important for the quality of the method used for therapeutic drug monitoring and routine analysis, and it is related to the signal-to-noise ratio. To maximize the sensitivity and avoid ionization suppression, mass spectrometry parameters were adjusted to get highest intensity. The values of signal-to-noise ratio were 6.96 and 12.46 for low limit of detection (LLOD) and low limit of quantitation (LLOQ), respectively. The values of these parameters are shown in Table 1. 

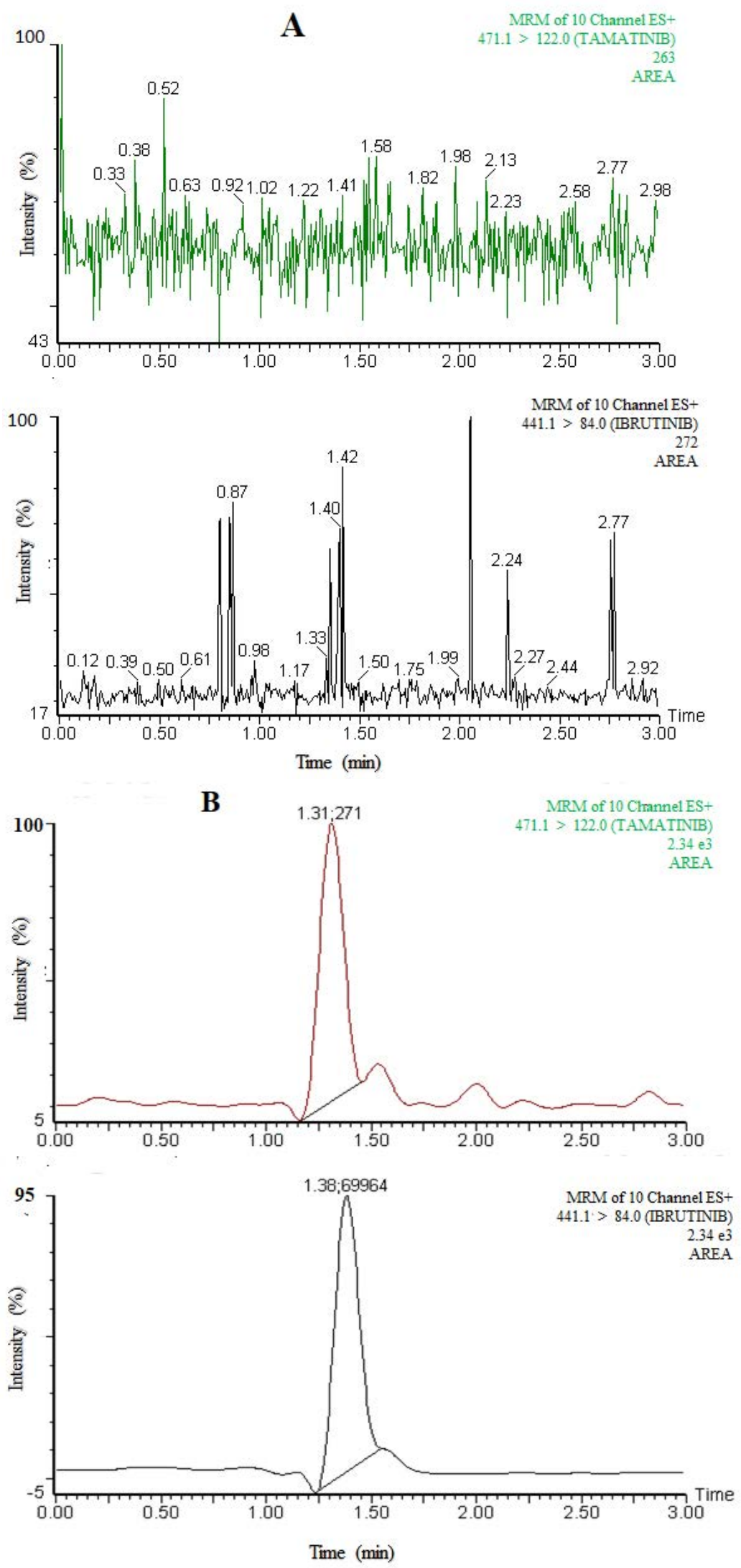

Figure 2. MRM Chromatograms of Tamatinib and Internal Standard in Blank Rat Plasma (A), and Plasma Spiked at LLOQ Level (B). 
Table 1. Average of Plasma Standard Calibration Curve of Tamatinib.

\begin{tabular}{|c|c|c|c|}
\hline \multicolumn{2}{|c|}{ Concentration (ng/mL) } & \multirow{2}{*}{$\begin{array}{c}\text { Precision } \\
\text { (\%) }\end{array}$} & \multirow{2}{*}{$\begin{array}{c}\text { Accuracy } \\
(\%)\end{array}$} \\
\hline $\begin{array}{l}\text { Theoretical } \\
\text { (ng/mL) }\end{array}$ & $\begin{array}{c}\text { Measured } \\
(\text { Mean } \pm \text { SD) }\end{array}$ & & \\
\hline 0.1 & $0.09 \pm 0.01$ & 12.1 & 87.3 \\
\hline 0.5 & $0.43 \pm 0.02$ & 4.7 & 86.3 \\
\hline 2.0 & $1.77 \pm 0.14$ & 7.9 & 88.3 \\
\hline 10.0 & $8.55 \pm 0.41$ & 4.8 & 85.5 \\
\hline 50.0 & $42.56 \pm 2.35$ & 5.5 & 85.1 \\
\hline 100.0 & $86.43 \pm 4.37$ & 5.1 & 86.4 \\
\hline 500.0 & $489.25 \pm 29.53$ & 6.0 & 97.8 \\
\hline 1000.0 & $872.41 \pm 42.5$ & 4.9 & 87.2 \\
\hline
\end{tabular}

\subsubsection{Linearity}

Linearity was determined by the regression coefficient from a plot of the ratios of tamatinib to IS (analyte/IS) against tamatinib concentration taken from CC. The method's linearity was within an acceptable range (0.997) (Table 1, Figure 3).

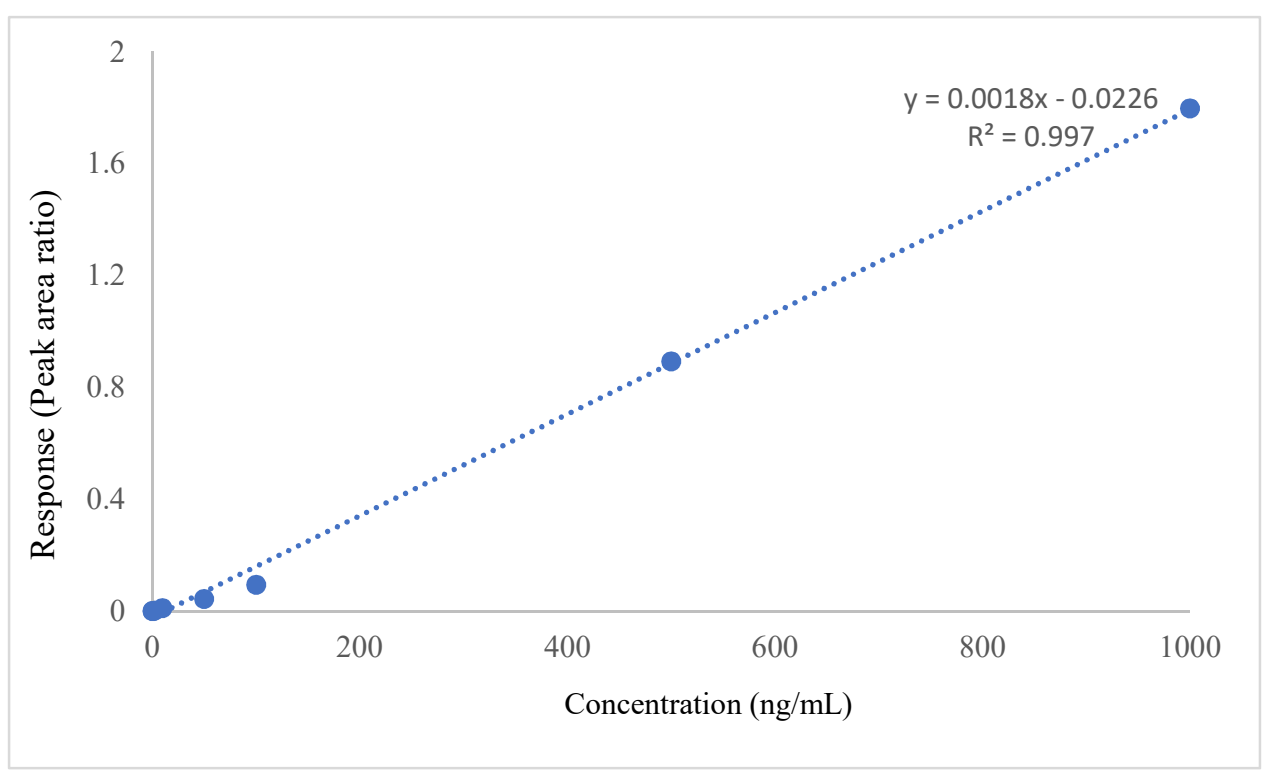

Figure 3. Standard Calibration Curve of Tamatinib.

\subsubsection{Accuracy and Precision}

The LLOQ and three levels of QC were analyzed in five replicates on 3 successive days to determine intra- and inter-day accuracy and precision, respectively. Accuracy is the closeness of a measured value to the actual one or the percentage deviation from nominal concentrations, and precision is expressed as $\mathrm{CV} \%$. Accuracy and precision of the method were within acceptable levels. The Guidelines stated accuracy and precision should be $\leq \pm 15 \%$ and within $\pm 15 \%$, respectively, except for LLOQ, for which they can be $\leq \pm 20 \%$ and within $\pm 20 \%$, respectively (Table 2 ).

\subsubsection{Recovery and Matrix Effects}

The average of recovery and matrix effect were measured by the analysis of QC samples. Mean recovery (method efficiency) was $81.23 \%$ among the three levels. Matrix effect was negligible, showing little ion suppression with an average of matrix effect less than $15 \%$ (Table 3). The recovery of the other solvents used, such as ethyl acetate, diethyl ether, and dichloromethane, ranged from $55 \%$ to $63 \%$. 
Table 2. Inter- and Intra-day Precision and Accuracy of Measurements of Tamatinib in Rat Plasma.

\begin{tabular}{ccccccc}
\hline Conc. & \multicolumn{3}{c}{ Intra-Day } & \multicolumn{3}{c}{ Inter-Day } \\
\cline { 2 - 7 }$(\mathbf{n g} / \mathbf{m L})$ & Mean \pm SD & $\begin{array}{c}\text { Accuracy } \\
(\%)\end{array}$ & $\begin{array}{c}\text { Precision } \\
(\%)\end{array}$ & Mean \pm SD & $\begin{array}{c}\text { Accuracy } \\
(\%)\end{array}$ & $\begin{array}{c}\text { Precision } \\
\text { CV (\%) }\end{array}$ \\
\hline 0.1 & $0.085 \pm 0.005$ & 85.0 & 5.8 & $0.086 \pm 0.001$ & 86.0 & 12.0 \\
0.3 & $0.255 \pm 0.012$ & 85.0 & 4.7 & $0.261 \pm 0.034$ & 87.0 & 13.0 \\
75 & $64.68 \pm 2.490$ & 86.2 & 3.9 & $66.5 \pm 6.720$ & 88.7 & 10.1 \\
750 & $648.5 \pm 36.000$ & 86.5 & 5.5 & $670.5 \pm 67.500$ & 89.4 & 10.1 \\
\hline
\end{tabular}

Table 3. Recovery (\%) and Matrix Effects for Tamatinib and Internal Standard.

\begin{tabular}{cccccccc}
\hline \multirow{2}{*}{ Compound } & \multirow{2}{*}{$\begin{array}{c}\text { Nominal Conc. } \\
\mathbf{( n g / m L )}\end{array}$} & \multicolumn{3}{c}{ Recovery } & \multicolumn{4}{c}{ Matrix Effects } \\
\cline { 3 - 8 } & & $\begin{array}{c}\text { Mean } \\
(\mathbf{n g} / \mathbf{m L})\end{array}$ & $\begin{array}{c}\text { Mean } \\
\mathbf{( \% )}\end{array}$ & $\begin{array}{c}\text { RSD } \\
\mathbf{( \% )}\end{array}$ & $\begin{array}{c}\text { Mean } \\
(\mathbf{n g} / \mathbf{m L})\end{array}$ & $\begin{array}{c}\text { Mean } \\
\mathbf{( \% )}\end{array}$ & $\begin{array}{c}\text { RSD } \\
\mathbf{( \% )}\end{array}$ \\
\hline \multirow{3}{*}{ Tamatinib } & 0.3 & 0.25 & 83.3 & 0.01 & 0.254 & 84.7 & 0.02 \\
& 75 & 62.4 & 83.2 & 2.79 & 64.4 & 85.9 & 3.37 \\
& 750 & 578.7 & 77.2 & 4.2 & 641.5 & 85.5 & 5.6 \\
\hline IS & 100 & 74.1 & 74.1 & 6.4 & 85.93 & 85.93 & 5.75 \\
\hline
\end{tabular}

\subsubsection{Stability}

Stability of tamatinib was examined under different processing and storage conditions using LQC, MQC, and HQC samples. The results demonstrated that tamatinib was stable in plasma under different conditions, showing percentage of deviation (precision) in all cases of $\leq 15 \%$. In addition, percentage accuracy of tamatinib was also within the $\pm 15 \%$ limit. This indicated that the method was stable during its application and use) Table 4).

Table 4. Stability of Tamatinib in Rat Plasma under Different Storage and Processing Conditions.

\begin{tabular}{ccccc}
\hline Stability & $\begin{array}{c}\text { Nominal } \\
\text { Concentration } \\
\text { (ng/mL) }\end{array}$ & $\begin{array}{c}\text { Measured } \\
\text { Concentration } \\
(\mathbf{n g} / \mathbf{m L})\end{array}$ & $\begin{array}{c}\text { Precision } \\
\mathbf{( \% )}\end{array}$ & $\begin{array}{c}\text { Accuracy } \\
\mathbf{( \% )}\end{array}$ \\
\hline Short-term & 0.3 & $0.26 \pm 0.03$ & 11.5 & 86.7 \\
& 75.0 & $64.65 \pm 3.47$ & 5.4 & 86.2 \\
Long-term & 750.0 & $640.10 \pm 43.19$ & 6.7 & 85.3 \\
\hline Thaw and freeze (three & 0.3 & $0.26 \pm 0.02$ & 7.7 & 86.7 \\
cycles from $-80^{\circ} \mathrm{C}$ & 75.0 & $66.10 \pm 7.77$ & 11.8 & 88.1 \\
to $\left.25^{\circ} \mathrm{C}\right)$ & 750.0 & $640.60 \pm 73.94$ & 11.5 & 85.4 \\
\hline & 75.0 & $0.27 \pm 0.01$ & 3.7 & 90.0 \\
Auto-sampler $(24 \mathrm{~h})$ & 750.0 & $67.40 \pm 2.79$ & 4.1 & 89.9 \\
& 75.0 & $649.20 \pm 69.95$ & 10.8 & 86.6 \\
\hline
\end{tabular}

\subsection{Application to a Pha Rmacokinetic Study}

In pharmacokinetic and clinical studies, fostamatinib was assessed by tamatinib plasma concentrations because the concentration of fostamatinib is low as it is rapidly metabolized to tamatinib [11]. The method was successfully applied to study pharmacokinetics of tamatinib in rats (Figure 4). The average of tamatinib maximum plasma concentration $\left(\mathrm{C}_{\max }\right)$ was $653.25 \pm 70.4 \mathrm{ng} / \mathrm{mL}$ and the corresponding time to reach $\mathrm{C}_{\max }\left(\mathrm{t}_{\max }\right)$ was $3.0 \mathrm{~h}$. The mean area under the time-concentration curve from 0 to $48 \mathrm{~h}$ $\left(\mathrm{AUC}_{0-48 \mathrm{~h}}\right)$ was $5644.4 \pm 1213.6 \mathrm{ng} / \mathrm{mL}$ and $\mathrm{AUC}_{0 \text {-inf }}$ was $6418.5 \pm 1495.7 \mathrm{ng} / \mathrm{mL}$. Median residence time (MRT) was $19.77 \pm 2.9 \mathrm{~h}$ and half-life $\left(\mathrm{t}_{1 / 2}\right)$ was $18.33 \pm 0.9 \mathrm{~h}$. (Table 5, 
Figure 5). Previously published tamatinib pharmacokinetics studies $[7,8,25]$ used some LC-MS/MS methods. However, these reports did not provide details about their validation methods including drug extraction and separation. Moreover, the sensitivity of our work exceeded the sensitivity in the reported analyses. The current method is characterized by high throughput reflecting short run times with a LLOQ of only $0.1 \mathrm{ng} / \mathrm{mL}$. Moreover, the extraction procedure is simple and quantitative. The method will be advantageous for therapeutic drug monitoring.

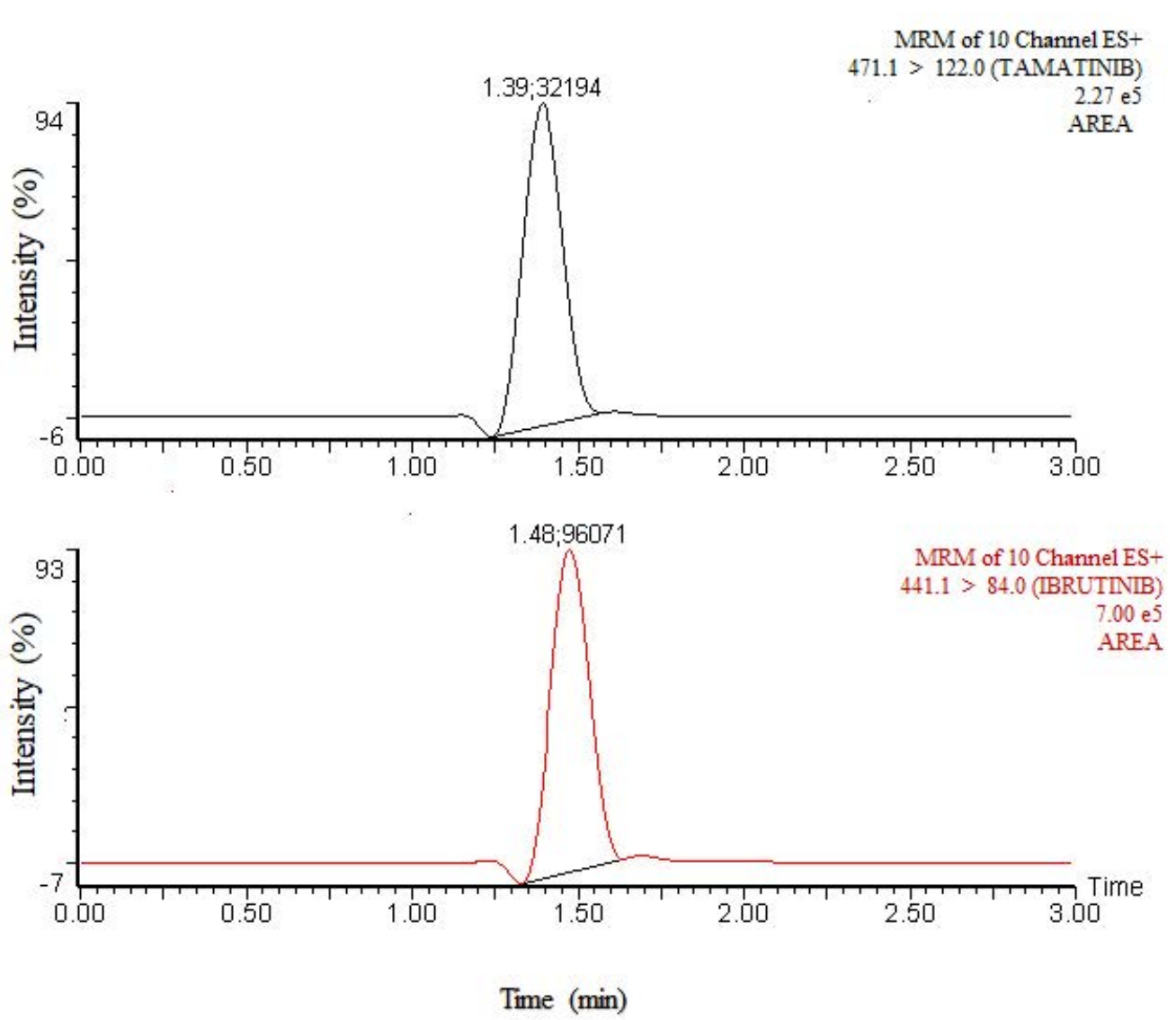

Figure 4. MRM Chromatograms of Tamatinib and Internal Standard in a Real Rat Plasma Sample Obtained at $1.0 \mathrm{~h}$ Following Oral Administration of $12.5 \mathrm{mg} / \mathrm{kg}$ of Fostamatinib.

Table 5. Pharmacokinetic of Tamatinib Following Administration of $12.5 \mathrm{mg} / \mathrm{kg}$ to Rats.

\begin{tabular}{cc}
\hline Parameters & Mean \pm SD \\
\hline $\mathrm{C}_{\max }(\mathrm{ng} / \mathrm{mL})$ & $653.25 \pm 70.4$ \\
\hline $\mathrm{t}_{\max }(\mathrm{h})$ & 3.0 \\
\hline $\mathrm{AUC}_{0-48}(\mathrm{ng} / \mathrm{mL})$ & $5644.4 \pm 1213.6$ \\
\hline $\mathrm{AUC}_{0-\text { inf }}(\mathrm{ng} / \mathrm{mL})$ & $6418.5 \pm 1495.7$ \\
\hline $\mathrm{K}_{\mathrm{el}}(\mathrm{h})$ & $0.04 \pm 0.001$ \\
\hline $\mathrm{t}_{1 / 2}(\mathrm{~h})$ & $18.33 \pm 0.9$ \\
\hline $\mathrm{MRT}(\mathrm{h})$ & $19.77 \pm 2.9$ \\
\hline Clearance $(\mathrm{L} / \mathrm{h})$ & $0.030 \pm 0.001$ \\
\hline Volume of Distribution $(\mathrm{L})$ & $0.019 \pm 0.001$ \\
\hline
\end{tabular}




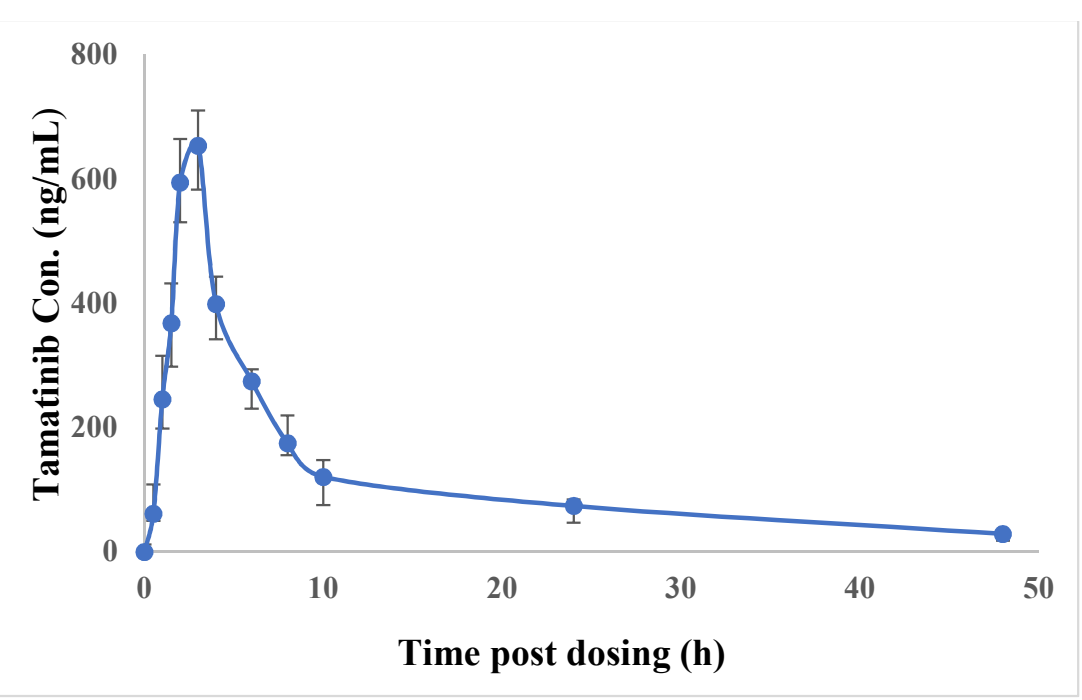

Figure 5. The Time Profile of Tamatinib Concentrations (Mean \pm SD) after Oral Administration of $12.5 \mathrm{mg} / \mathrm{kg}$ of Fostamatinib.

\subsection{Investigation of the Method Greenness}

The proposed method fulfills the criteria of the greenness profile according to the emergency planning and community right-to-know act, 2004; Code of Federal Regulations, 2014. None of the used solvents are listed in the PBT list (persistent, bio-, accumulative, and toxic) [26] and are not corrosive, not a hazard. The amount of waste is less than 50 g per sample [27].

The greenness of the analytical method was evaluated using the AGREE green program as well as an analytical eco-scale. The AGREE green program provides information on the whole procedure. The proposed method scored 0.73 point from 1.0, which indicated that the method was good from the ecological point of view (Figure 6). Application of the analytical eco-scale indicated that the proposed method acquired 82 points from 100 (Table 6, Figure S1), and an analytical eco-scale score of more than 50 points represents an good result of green analysis [28].

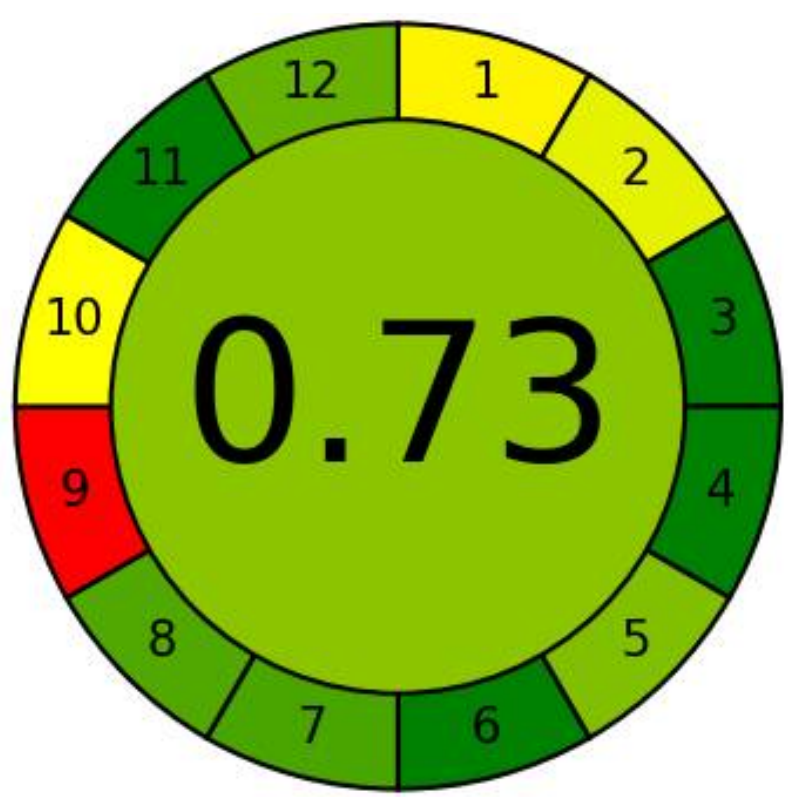

Figure 6. An AGREE Pictogram for Evaluation of the Proposed Method's Greenness. 
Table 6. The Penalty Points of the Method for the Determination and Quantitation of the Tamatinib in Plasma.

\begin{tabular}{ccc}
\hline Parameter & Value & Penalty Points \\
\hline Dimethyl Sulfoxide & $<10 \mathrm{~mL}(\mathrm{~g})$ & 1 \\
Aceonitrile & $<10 \mathrm{~mL}(\mathrm{~g})$ & 4 \\
Methanol & $<10 \mathrm{~mL}(\mathrm{~g})$ & 6 \\
Formic acid & $<10 \mathrm{~mL}(\mathrm{~g})$ & 1 \\
Ammonium acetate & $<10 \mathrm{~mL}(\mathrm{~g})$ & 1 \\
Waste & $1.8 \mathrm{~mL} / \mathrm{run}(\mathrm{g})$ & 3 \\
Instrument energy & $>1.5 \mathrm{kWh}$ & 2 \\
Total penalty points & & 18 \\
Eco-scale score & & 82 \\
\hline
\end{tabular}

\section{Materials and Methods}

\subsection{Chemicals}

Fostamatinib sodium (Purity, 98\%) was purchased from "Toronto Research Chemicals" (North York, ON, Canada), tamatinib (purity; $\geq 98.0 \%$ ), ibrutinib (IS, purity $\geq 97.0 \%$ ) (Figure 7) was obtained from "Beijing Mesochem Technology Co. Ltd.". Beijing, China (Figure 7). Methyl tert-butyl ether (MTBE) were obtained from Central Drug Housing Ltd. (New Delhi, India). sulphoxide Acetonitrile and methanol (HPLC grade) were supplied by "BDH Laboratory, Lutterworth, UK". Dimethyl (DMSO) (Loba Chemie Pvt. Ltd. Mumbai, India), ammonium acetate (Qualikemes Fine Chem. Pvt. Ltd., Vadodara, India) and deionized water from the Milli-Q system Millipore, M (oscheim Cedex, France) were used in the preparation of the buffer of the mobile phase.

\subsection{Instrumentation}

The analysis was performed on Waters ${ }^{\circledR}$ Acquity H-Class UPLC ${ }^{\circledR}$ tandem triple quadrupole mass spectrometer (TQD) (Waters, Milford, USA). The H-Class UPLC ${ }^{\circledR}$ system contained Acquity sample manager and Acquity quaternary solvent manager. TQD was equipped with electrospray ionization (ESI) probe. Samples were detected and quantified in multiple reaction monitoring (MRM) mode. Chromatographic separation of tamatinib and IS was performed using Acquity TM CSH C18 $(2.1 \mathrm{~mm} \times 100 \mathrm{~mm}, 1.7 \mu \mathrm{m})$ column. Mobile phase composition was $10 \mathrm{mM}$ ammonium acetate and acetonitrile (10:90). The mobile phase was adjusted at $0.25 \mathrm{~mL} / \mathrm{min}$. The MRM transitions of $471.1>122.0$ and $441.1>84.0$ were used for detection tamatinib and IS, respectively. The system was operated with the MassLynx program (Waters corporation, Milford, MA 01757, USA (Milford, MA 01757, USA), and the data acquisition used the TargetLynx ${ }^{\mathrm{TM}}$ software. Nitrogen (purity 99.999\%) was used as a desolvation gas and argon as a collision gas. MS/MS parameters were optimized for tamatinib and IS by direct infusion of their solutions $(500 \mathrm{ng} / \mathrm{mL})$ individually at a flow rate of $5 \mu \mathrm{L} / \mathrm{min}$. The values of the optimized parameters were illustrated in Table 7.

\subsection{Preparation of Stock Solutions}

Tamatinib was dissolved in DMSO to prepare a stock solution of $4 \mathrm{mg} / \mathrm{mL}$. The solution was diluted 20-fold with methanol to achieve a concentration of $200 \mu \mathrm{g} / \mathrm{mL}$. An IS working solution of $10 \mu \mathrm{g} / \mathrm{mL}$ was prepared in acetonitrile. The tamatinib working solution was used to prepare calibration curves (CC) and quality control (QC) samples in rat plasma. CC range was $0.1-1000 \mathrm{ng} / \mathrm{mL}$. QC samples were prepared by spiking rat plasma with the tamatinib working solution at low (LQC, $0.3 \mathrm{ng} / \mathrm{mL}$ ), medium (MQC, $75 \mathrm{ng} / \mathrm{mL}$ ) and high (HQC, $750 \mathrm{ng} / \mathrm{mL}$ ) concentrations that covered the entire range of CC. 
<smiles>COc1cc(Nc2ncc(F)c(Nc3ccc4c(n3)N(COP(=O)(O)O)C(=O)C(C)(C)O4)n2)cc(OC)c1OC</smiles>

A<smiles>COc1cc(Nc2ncc(F)c(Nc3ccc4c(n3)NC(=O)C(C)(C)O4)n2)cc(OC)c1OC</smiles>

B<smiles>C=CC(=O)N1CCCC(n2nc(-c3ccc(Oc4ccccc4)cc3)c3c(N)ncnc32)C1</smiles>

C

Figure 7. Chemical Structure of Fostamatinib (A), Tamatinib (B), and Ibrutinib (C).

Table 7. Mass Optimization Parameters for Tamatinib and Ibrutinib (IS).

\begin{tabular}{ccc}
\hline Parameters & Tamatinib & Ibrutinib \\
\hline I. Compound Parameters & & \\
\hline Precursor ion & 471.1 & 441.1 \\
\hline Product ion & 122.0 & 84.0 \\
\hline Dwell time $(\mathrm{s})$ & 0.25 & 0.25 \\
\hline Cone voltage $(\mathrm{V})$ & 68 & 52 \\
\hline Collision energy $(\mathrm{eV})$ & 50 & 46 \\
\hline II. Instrument Parameters & & \\
\hline Collision gas flow rate $(\mathrm{L} / \mathrm{h})$ & 0.1 & 6.1 \\
\hline Nitrogen flow rate $(\mathrm{L} / \mathrm{h})$ & 600 & 150 \\
\hline Source Temperature $\left({ }^{\circ} \mathrm{C}\right)$ & 150 & 350 \\
\hline Desolvation temperature $\left({ }^{\circ} \mathrm{C}\right)$ & 350 & \\
\hline
\end{tabular}

\subsection{Sample Preparation}

Plasma extraction of tamatinib was carried out using liquid-liquid extraction. In a $2 \mathrm{~mL}$ vial, $10 \mu \mathrm{L}$ of IS $(10 \mu \mathrm{g} / \mathrm{mL})$ was added to $100 \mu \mathrm{L}$ plasma samples followed by the addition of acetonitrile $(50 \mu \mathrm{L})$. Samples were vortex-mixed for $30 \mathrm{~s}$, and $1 \mathrm{~mL}$ of MTBE was added. All samples were vortex-mixed for $1 \mathrm{~min}$, then centrifuged at $8{ }^{\circ} \mathrm{C}$ for $10 \mathrm{~min}$ 
at $4500 \mathrm{~g}$. After centrifugation, the upper layer was transferred to $2 \mathrm{~mL}$ tubes and dried using a vacuum concentrator at $40^{\circ} \mathrm{C}$. The residue was reconstituted with $100 \mu \mathrm{L}$ of the mobile phase and a volume of $5 \mu \mathrm{L}$ was injected into the UPLC-MS/MS.

\subsection{Method Validation}

The method was validated in compliance with the FDA bioanalytical method validation guidelines [25].

\subsubsection{Specificity and Sensitivity}

The absence of interference at elution times of the studied drug and IS was evaluated by comparing chromatograms of plasma sample spiked with tamatinib at the lowest concentration (LLOQ) with that of blank plasma obtained from six different rats for any interference at the retention time of tamatinib and IS. According to the signal-to-noise ratio, low limit of detection (LLD) and LLQ can be determined. It should be not less than 5:1 and 10:1 for LLD and LLQ, respectively.

\subsubsection{Linearity}

Linearity represented by plotting a graph of the relation between tamatinib analyte nominal concentration and analysis response (ratio of the analyte peak area and IS). Linearity was evaluated using CC in rat plasma. CC were prepared with nine different concentrations of tamatinib in the range of $0.1-1000 \mathrm{ng} / \mathrm{mL}(0.1,0.5,2.0,10.0,50.0,100.0,500.0$, 1000.0) and $10 \mu \mathrm{L}$ of IS was added in the CC samples. Peak area ratios (tamatinib/IS) were plotted against tamatinib concentration. The linearity expressed by correlation coefficient $(r)$ was evaluated using weighted $\left(1 / x^{2}\right)$ linear regression.

$$
r=\frac{n\left(\sum x y\right)-\left(\sum x\right)\left(\sum y\right)}{\Delta \sqrt{n x^{2}}-\left(\sum n\right) n^{2}}
$$

\subsubsection{Accuracy and Precision}

Accuracy and precision of the method was achieved using quality control (QCs) samples. Three QC samples at low, medium, and high concentrations along with LLOQ samples were analyzed. LLOQ should be quantitatively determined with suitable precision and accuracy $( \pm 20 \%)$ and with a signal more than 5 time the background noise. Six sets of QC samples and LLOQ were analyzed on 3 successive days for evaluation of intra-and inter-day precision and accuracy.

\subsubsection{Recovery and Matrix Effect}

The recovery and the matrix effects were determined in rat plasma samples through the anlysis of three QC concentrations $(0.3,75$ and $750 \mathrm{ng} / \mathrm{mL})$ level in five replicates. The percentage recovery of analyte was calculated by comparing the percentage of peak area response of plasma samples spiked with analyte before extraction with those fortified after the extraction. The matrix effects were evaluated by post extraction (quantitative) method. The percentage of matrix effects were calculated by comparing the peak area response of plasma samples spiked with analyte after extraction with those of aqueous samples. The same procedure was followed for the evaluation of recovery and matrix effects for IS.

\subsubsection{Stability}

The stability of tamatinib was studied at different conditions using QC samples at three levels (LQC, MQC, and HQC) in six replicates. Short-term stability was evaluated at $22-25^{\circ} \mathrm{C}$ for $6 \mathrm{~h}$, which represented the processing time. Autosampler stability at ambient temperature for $24 \mathrm{~h}$, long-term stability $\left(-80^{\circ} \mathrm{C}\right.$ for 6 weeks), and three cycles of thaw and freeze $\left(-80\right.$ and $\left.25^{\circ} \mathrm{C}\right)$ were evaluated. The actual concentrations of QCs samples (LQC, MQC, and HQC) under the stability test condition were compared against freshly 
prepared samples. Moreover, stock solution and working solution stability was evaluated at refrigerator temperature $\left(4^{\circ} \mathrm{C}\right)$ for 2 weeks.

\subsubsection{Application of Pharmacokinetic Study}

Eight Wistar male rats weighing $210 \pm 20 \mathrm{~g}$ (aged about 2 months) were provided by National Organization for Drug Control and Research, Cairo, Egypt. Rats were placed in cages in optimum conditions of humidity $(40-60 \%)$ and temperature $\left(22-26^{\circ} \mathrm{C}\right)$ with regular $12 \mathrm{~h}$ day-night cycle. No diet was available for animals for $10 \mathrm{~h}$ prior and $1 \mathrm{~h}$ post drug administration. Water was available ad libitum. Rats were administered orally (using the gavage technique) $12.5 \mathrm{mg} / \mathrm{kg}$ (the middle dose used in the work of Clemens et al. [14]) fostamatinib as a suspension in 1\% sodium carboxymethylcellulose [14]. Under light anesthesia, blood samples $(0.3 \mathrm{~mL})$ were collected from orbital sinus, in heparinized tube, at different time points; $0,0.5,1.0,2.0,3.0,4.0,6.0,8.0,12.0,24.0$, and $48.0 \mathrm{~h}$ after drug administration. Plasma samples were obtained by centrifugation at $3000 \mathrm{~g}$ for $3 \mathrm{~min}$ and kept frozen at $-80^{\circ} \mathrm{C}$ until analysis. Non-compartmental analysis with the trapezoidal rule was used for estimation of pharmacokinetic parameters. These parameters were calculated using WinNonlin software (Pharsight Co., Mountain View, CA, USA).

The experimental protocol approval was obtained by the ethics committee at the National Organization for Drug Control (NODCAR/VI/47/19).

\section{Conclusions}

In this work, we established a sensitive, fast, reproducible, and reliable method for determination of tamatinib in plasma samples. Tamatinib was extracted by liquid-liquid procedure using MTBE. The matrix effect was negligible and the recovery for both analyte and IS compound were satisfactory. This method showed good linearity with high selectivity, sensitivity, and precision as per FDA guideline. The method was green and eco-friendly, and it was validated and successfully used in tamatinib pharmacokinetic characterization in rats. Therefore, the assay can be used for TDM and pharmacokinetic studies.

Supplementary Materials: The following are available online, Figure S1. Analytical Greenness report sheet and Criteria.

Author Contributions: Conceptualization, E.E. and Y.A.A.; methodology, E.E.; software, E.E.; validation, E.E., M.I.; formal analysis, A.Y.A.S., R.A.; investigation, E.E.; data curation, A.Y.A.S.; writing—original draft preparation, E.E., R.A.; writing—review and editing, Y.A.A.; visualization, E.E.; supervision, E.E., Y.A.A.; project administration, Y.A.A., E.E.; funding acquisition, Y.A.A. All authors have read and agreed to the published version of the manuscript.

Funding: This research was funded by Deanship of Scientific Research at King Saud University, grant number RG-1435-072 and the APC was funded by Deanship of Scientific Research at King Saud University.

Institutional Review Board Statement: The study was conducted according to the guidelines of the Declaration of Helsinki and approved by the Ethics Committee of National Organization for Drug Control and Research, Cairo, Egypt (protocol code 229 and 20 January 2020).

Informed Consent Statement: Not applicable.

Acknowledgments: The authors would like to extend their sincere appreciation to the Deanship of Scientific Research at King Saud University, Riyadh, Saudi Arabia for funding this work through the research group no RG-1435-072. We also wish to thank Marwa Tammam and bioavailability center team at National Organization for Drug Control and Research, Cairo, Egypt, for their assistance in the practical part of the study.

Conflicts of Interest: The authors declare no conflict of interest.

Sample Availability: Not available. 


\section{References}

1. Colado, A.; Almejún, M.B.; Podaza, E.; Risnik, D.; Stanganelli, C.; Elías, E.E.; Dos Santos, P.; Slavutsky, I.; Grecco, H.F.; Cabrejo, M.; et al. The kinase inhibitors R406 and GS-9973 impair T cell functions and macrophage-mediated anti-tumor activity of rituximab in chronic lymphocytic leukemia patients. Cancer Immunol. Immunother. 2017, 66, 461-473. [CrossRef]

2. Suljagic, M.; Longo, P.G.; Bennardo, S.; Perlas, E.; Leone, G.; Laurenti, L.; Efremov, D.G. The Syk inhibitor fostamatinib disodium (R788) inhibits tumor growth in the E $\mu$-TCL1 transgenic mouse model of CLL by blocking antigen-dependent B-cell receptor signaling. Blood 2010, 116, 4894-4905. [CrossRef]

3. Maringwa, J.; Kågedal, M.; Hamrén, U.W.; Martin, P.; Cox, E.; Hamrén, B. Pharmacokinetic-pharmacodynamic modeling of fostamatinib efficacy on ACR20 to support dose selection in patients with rheumatoid arthritis (RA). J. Clin. Pharmacol. 2015, 55, 328-335. [CrossRef] [PubMed]

4. Kang, Y.; Jiang, X.; Qin, D.; Wang, L.; Yang, J.; Wu, A.; Huang, F.; Ye, Y.; Wu, J. Efficacy and Safety of Multiple Dosages of Fostamatinib in Adult Patients With Rheumatoid Arthritis: A Systematic Review and Meta-Analysis. Front. Pharmacol. 2019, 10, 897. [CrossRef]

5. Skinner, M.; Philp, K.; Lengel, D.; Coverley, L.; Bergström, E.L.; Glaves, P.; Musgrove, H.; Prior, H.; Braddock, M.; Huby, R.; et al. The contribution of VEGF signalling to fostamatinib-induced blood pressure elevation. Br. J. Pharmacol. 2014, 171, $2308-2320$. [CrossRef] [PubMed]

6. Bussel, J.; Arnold, D.M.; Grossbard, E.; Mayer, J.; Treliński, J.; Homenda, W.; Hellmann, A.; Windyga, J.; Sivcheva, L.; Khalafallah, A.; et al. Fostamatinib for the treatment of adult persistent and chronic immune thrombocytopenia: Results of two phase 3, randomized, placebo-controlled trials. Am. J. Hematol. 2018, 93, 921-930. [CrossRef]

7. Pamuk, O.N.; Can, G.; Ayvaz, S.; Karaca, T.; Pamuk, G.E.; Demirtas, S.; Tsokos, G.C. Spleen tyrosine kinase (Syk) inhibitor fostamatinib limits tissue damage and fibrosis in a bleomycin-induced scleroderma mouse model. Clin. Exp. Rheumatol. 2015, 33, S15-S22.

8. Shinde, A.; Hardy, S.D.; Kim, D.; Akhand, S.S.; Jolly, M.K.; Wang, W.H.; Anderson, J.C.; Khodadadi, R.B.; Brown, W.S.; George, J.T.; et al. Spleen Tyrosine Kinase-Mediated Autophagy Is Required for Epithelial-Mesenchymal Plasticity and Metastasis in Breast Cancer. Cancer Res. 2019, 15, 1831-1843. [CrossRef] [PubMed]

9. Morales-Torres, J. The status of fostamatinib in the treatment of rheumatoid arthritis. Expert Rev. Clin. Immunol. 2012, 8, 609-615. [CrossRef]

10. Kuiatse, I.; Baladandayuthapani, V.; Lin, H.Y.; Thomas, S.K.; Bjorklund, C.C.; Weber, N.M.; Wang, M.; Shah, J.J.; Zhang, X.-D.; Jones, R.J.; et al. Targeting the Spleen Tyrosine Kinase with Fostamatinib as a Strategy against Waldenström Macroglobulinemia. Clin. Cancer Res. 2015, 21, 2538-2545. [CrossRef]

11. Martin, P.; Gillen, M.; Millson, D.; Oliver, S.; Brealey, C.; Surry, D.; Sweeny, D.; Lau, D.; Leese, P. Effects of Fostamatinib on the Pharmacokinetics of the CYP2C8 Substrate Pioglitazone: Results from in vitro and Phase 1 Clinical Studies. Clin. Pharmacol. Drug Dev. 2016, 5, 170-179. [CrossRef]

12. Baluom, M.; Samara, E.; Grossbard, E.B.; Lau, D.T. Fostamatinib: A Syk-kinase inhibitor; does not affect methotrexate pharmacokinetics in patients with rheumatoid arthritis. J. Clin. Pharmacol. 2011, 51, 1310-1318. [CrossRef] [PubMed]

13. Herman, S.E.; Barr, P.M.; McAuley, E.M.; Liu, D.; Wiestner, A.; Friedberg, J.W. Fostamatinib inhibits B-cell receptor signaling, cellular activation and tumor proliferation in patients with relapsed and refractory chronic lymphocytic leukemia. Leukemia 2013, 8, 1769-1773. [CrossRef]

14. Clemens, G.R.; Schroeder, R.E.; Magness, S.H.; Weaver, E.V.; Lech, J.W.; Taylor, V.C.; Masuda, E.S.; Baluom, M.; Grossbard, E.B. Developmental toxicity associated with receptor tyrosine kinase Ret inhibition in reproductive toxicity testing. Birth Defects Res. Part A Clin. Mol. Teratol. 2009, 85, 130-136. [CrossRef] [PubMed]

15. Zhu, Y.; Herlaar, E.; Masuda, E.; Burleson, G.R.; Nelson, A.J.; Grossbard, E.B.; Clemens, G.R. Immunotoxicity assessment for the novel Spleen tyrosine kinase inhibitor R406. Toxicol. Appl. Pharmacol. 2007, 221, 268-277. [CrossRef] [PubMed]

16. Smith, J.; McDaid, J.P.; Bhangal, G.; Chawanasuntorapoj, R.; Masuda, E.S.; Cook, H.T.; Pusey, C.D.; Tam, F.W. A Spleen Tyrosine Kinase Inhibitor Reduces the Severity of Established Glomerulonephritis. J. Am. Soc. Nephrol. 2010, 21, 231-236. [CrossRef]

17. Braselmann, S.; Taylor, V.; Zhao, H.; Wang, S.; Sylvain, C.; Baluom, M.; Qu, K.; Herlaar, E.; Lau, A.; Young, C.; et al. R406: An orally available spleen tyrosine kinase inhibitor blocks fc receptor signaling and reduces immune complex-mediated inflammation. J. Pharmacol. Exp. Ther. 2006, 319, 998-1008. [CrossRef] [PubMed]

18. Baluom, M.; Grossbard, E.B.; Mant, T.; Lau, D.T.W. Pharmacokinetics of fostamatinib, a spleen tyrosine kinase (SYK) inhibitor, in healthy human subjects following single and multiple oral dosing in three phase I studies. Br. J. Clin. Pharmacol. 2013, 76, 78-88. [CrossRef]

19. Sweeny, D.J.; Li, W.; Clough, J.; Bhamidipati, S.; Singh, R.; Park, G.; Baluom, M.; Grossbard, E.; Lau, D.T.-W. Metabolism of Fostamatinib, the Oral Methylene Phosphate Prodrug of the Spleen Tyrosine Kinase Inhibitor R406 in Humans: Contribution of Hepatic and Gut Bacterial Processes to the Overall Biotransformation. Drug Metab. Dispos. 2010, 38, 1166-1176. [CrossRef] [PubMed]

20. Martin, P.; Cheung, S.Y.; Yen, M.; Han, D.; Gillen, M. Characterization of the disposition of fostamatinib in Japanese subjects including pharmacokinetic assessment in dry blood spots: Results from two phase I clinical studies. Eur. J. Clin. Pharmacol. 2016, 72, 61-71. [CrossRef] 
21. Pine, P.R.; Chang, B.; Schoettler, N.; Banquerigo, M.L.; Wang, S.; Lau, A.; Zhao, F.; Grossbard, E.B.; Payan, D.G.; Brahn, E. Inflammation and bone erosion are suppressed in models of rheumatoid arthritis following treatment with a novel Syk inhibitor. Clin. Immunol. 2007, 124, 244-257. [CrossRef]

22. Friedberg, J.W.; Sharman, J.; Sweetenham, J.; Johnston, P.B.; Vose, J.M.; Lacasce, A.; Schaefer-Cutillo, J.; De Vos, S.; Sinha, R.; Leonard, J.P.; et al. Inhibition of Syk with fostamatinib disodium has significant clinical activity in non-Hodgkin lymphoma and chronic lymphocytic leukemia. Blood 2010, 115, 2578-2585. [CrossRef]

23. Chang, H.-C.; Huang, D.-Y.; Wu, M.-S.; Chu, C.-L.; Tzeng, S.-J.; Lin, W.-W. Spleen tyrosine kinase mediates the actions of EPO and GM-CSF and coordinates with TGF- $\beta$ in erythropoiesis. Biochim. Biophys. Acta Mol. Cell Res. 2017, 1864, 687-696. [CrossRef] [PubMed]

24. Lengel, D.; Bergström, E.L.; Barthlow, H.; Oldman, K.; Musgrove, H.; Harmer, A.; Valentin, J.-P.; Duffy, P.; Braddock, M.; Curwen, J. Prevention of fostamatinib-induced blood pressure elevation by antihypertensive agents. Pharmacol. Res. Perspect. 2015, 3, e00176. [CrossRef] [PubMed]

25. Guidance for Industry on Bioanalytical Method Validation; Center for Drug Evaluation and Research and US Food and Drug Administration: Rockville, MD, USA, 2018. Available online: https://www.fda.gov/files/drugs/published/BioanalyticalMethod-Validation-Guidance-for-Industry.pdf (accessed on 2 September 2020).

26. Emergency Planning and Community Right-to-Know Act (EPCRA). Available online: https://www.epa.gov/epcra (accessed on 2 September 2020).

27. Abdelaleem, E.A.; Abdelwahab, N.S. Green chromatographic method for analysis of some anti-cough drugs and their toxic impurities with comparison to conventional methods. Saudi Pharm. J. 2018, 26, 1185-1191. [CrossRef]

28. Gałuszka, A.; Migaszewski, Z.; Konieczka, P.; Namiesnik, J. Analytical Eco-Scale for assessing the greenness of analytical procedures. TrAC Trends Anal. Chem. 2012, 37, 61-72. [CrossRef] 